\title{
OBITUARY
}

\section{LIONEL DAVID BARNETT}

With the death of Dr. L. D. Barnett almost the last of a great generation of Indologists has passed away. Born in Liverpool on 21 October 1871, he had a brilliant career at the Victoria University of Manchester and Liverpool and afterwards at Cambridge, where he entered Trinity College in 1892, completing his Classical Tripos in 1896, when he won the Chancellor's Medal. For two years, as Craven Student, he studied in Halle and Berlin, returning to Cambridge to receive his M.A. in 1899, and gaining a doctorate of Victoria University in the following year. He was disappointed at not obtaining a fellowship at Cambridge, and for a while considered emigrating to New Zealand, but ultimately decided to accept an assistant keepership in the Department of Oriental Printed Books and Manuscripts of the British Museum, where he worked for sixty years. He had studied Sanskrit under Professor E. B. Cowell, and from 1899 onwards he devoted himself to Indian studies, and to the cataloguing of the splendid Indian collection of the Museum Library. In 1908 he was appointed to the keepership of his department, a post which he held until 1936, at first concurrently with a part-time professorship of Sanskrit at University College, London. On the foundation of the School of Oriental Studies in 1917 and the appointment of a full-time Professor, Dr. Barnett became part-time lecturer in Sanskrit, to which were later added teaching responsibilities in ancient Indian history and epigraphy. He retired from the British Museum in 1936 on account of age, but still continued his work at the School. In 1940, when he was already 69 years old, he was appointed its Librarian, a post which he held until 1947.

When he retired from the School, at the age of 76 , he was immediately invited to return to the British Museum Library, which was then in dire need of assistance in its Oriental Department. Here he continued to work until about two months before his death, and the diamond jubilee of his entering the service of the Museum was celebrated in August 1959. He was recovering from a serious illness and was planning to return to his work at the Museum when he died suddenly on 28 January of this year, leaving a son (Dr. R. D. Barnett, Keeper of Western Asiatic Antiquities at the British Museum) and a daughter. Mrs. Barnett, née Blanche Berliner, whom he married in 1901, predeceased him, dying in 1955.

Dr. Barnett's life as a scholar was divided between the British Museum, the School of Oriental and African Studies, and the Royal Asiatic Society. Of his long career at the Museum a splendid memorial survives in his great series of catalogues, of which the earliest (A supplementary catalogue of Sanskrit, Pali and Prakrit books acquired during the years 1892-1906) was published in 1908, and the latest, the catalogue of Panjabi books, was left two-thirds finished on his death. He was beloved by all his colleagues in the Museum, who remember him as invariably courteous and helpful, and as a model of punctuality, accuracy, 


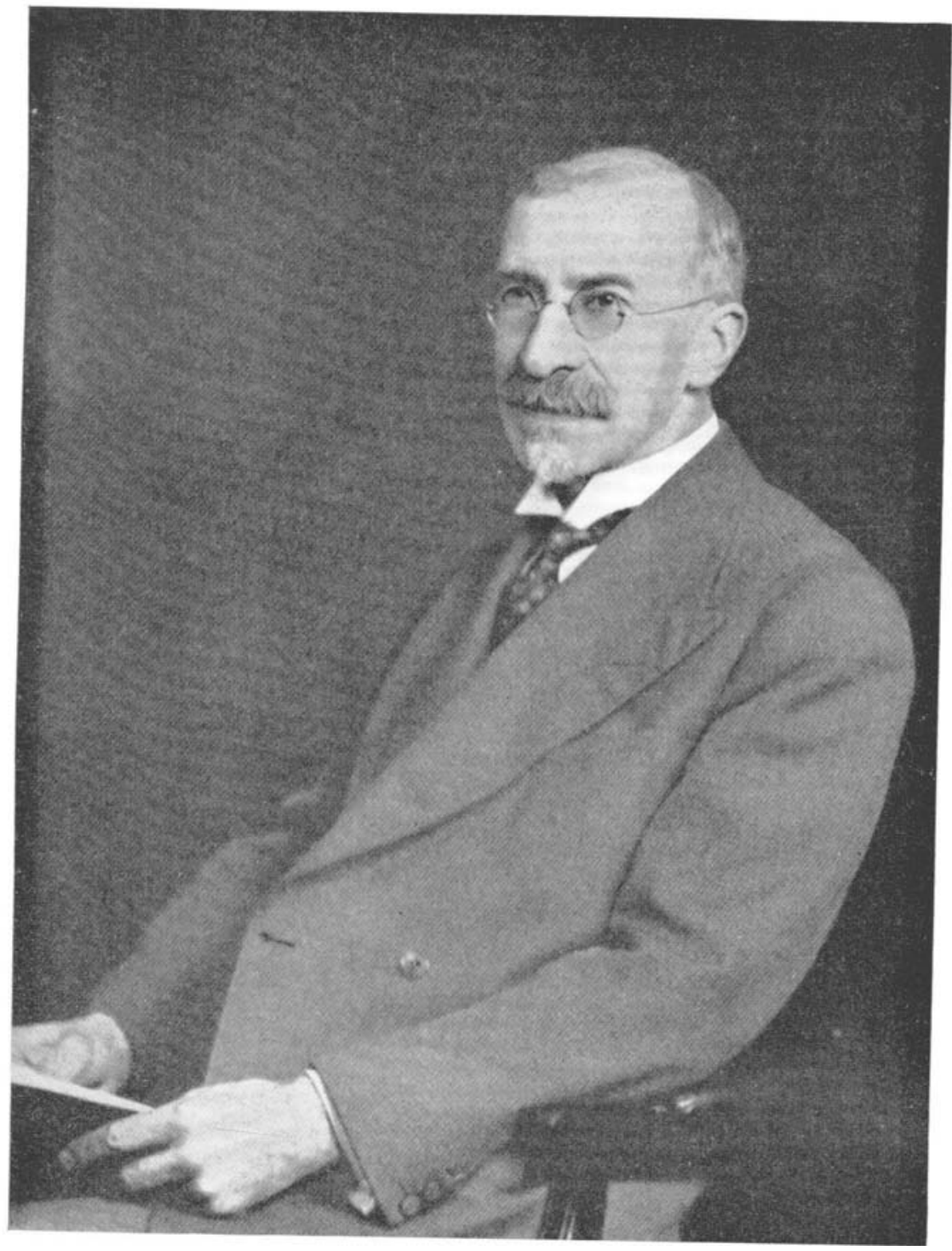

Lionel David Barnett 
and efficiency. Scorning secretarial assistance he served as his own clerk and typist, and attained proficiency in the use of a typewriter equal to that of many professionals.

At the School he was almost as familiar a figure as at the British Museum. Quiet and rather reserved, he was an able teacher. His lectures were terse and to the point, delivered in a slow, clear voice, with few concessions to his listeners except for occasional slight touches of dry humour. It was as a supervisor of research that Dr. Barnett showed his greatest skill as a teacher. Though he was always a little aloof from his students, and would make no concessions in his demand for scrupulous accuracy, he won their confidence and deep affection by his unfailing interest and unstinted help, and under his guidance numerous Indian historians, now themselves nearing the age of retirement, produced works of primary importance. He is still remembered lovingly by many former students in India, a land which he never visited, despite his deep knowledge of its ancient culture. His period of service as Librarian at the School was marked by the transfer of the Library to the present building, a difficult. operation which, despite his already advanced years, he superintended with enthusiasm and efficiency. His retirement in 1947 was marked by a special presentation number of BSOAS (Vol. XII, Parts 3 and 4, 1948), where a complete list of his published works and reviews down to 1947 may be found.

Dr. Barnett's first contribution to Indology appeared in 1901 in JRAS ('The Upäsakajanälañkära', pp. 87-90), and one of his last contributions, an obituary notice of Professor F. W. Thomas (JRAS, 1957, pp. 142-3), was published in the same journal. He served the Society devotedly throughout his career, becoming one of its Vice-Presidents in 1934 and its Honorary Librarian in 1939. In another field, he rendered great service to the Spanish and Portuguese Synagogue, Bevis Marks, of which he was a much respected elder, by arranging and cataloguing its very valuable archives, some of which were printed in his own translation (El Libro de los Acuerdos . . . , Oxford, 1931). Despite his profound knowledge of and qualified sympathy with the religions of India he was always firm in his own faith, and he loyally served his community throughout his life, though he was one of the small minority of Jews who strongly disapproved of Zionism and the formation of the state of Israel.

As well as his catalogues, his early classical translations, and his works on Jewish history, he wrote much on Indology, covering a very wide field from religion to palæography and chronology. Perhaps his most important publication, other than the British Museum catalogues, was Antiquities of India (London, 1913), a survey of many aspects of ancient Indian civilization which still forms a work of reference of much value. He also produced numerous translations of Indian literature in graceful English prose, several of which were published in Murray's 'Wisdom of the East' series. For all his great erudition. he did not neglect the general reader, and his work has done much to spread the knowledge of Indian culture in the West. He was an indefatigable 
reviewer (chiefly in $J R A S$ ), justly dealing out praise and blame, the latter often with laconic irony.

He was a man devoted not merely to scholarship but to service. He gave of himself ungrudgingly to his profession, to his Synagogue, to his students, and to his friends. Modestly and without fuss he served to the last, remaining at his desk in the British Museum at an age when most scholars are already in their graves. Honours came to him-Fellowship of the British Academy in 1936, Companionship of the Bath in 1937, the Royal Asiatic Society's Gold Medal in 1950, and the Sir William Jones Medal of the Asiatic Society of Bengal in 1960, only a week or two before his death. But though he appreciated such recognition, it left him untouched-simple, retiring, and unassuming, despite his brilliant intellect and phenomenal memory. To all his friends and students his memory will be a constant source of inspiration and guidance, and it is with a deep sense of personal loss that the very last of Dr. Barnett's students to gain his doctorate records his respect and affection for his venerable guru.

A. L. BASHAM 